\section{AL-AZHAR}

Assiut Dental Journal
The Official Publication of The

Faculty of Dental medicine.

Al-Azhar Assiut Uniuersity.

Egypt

\title{
Comparative Analysis of the Effect of Border Molding Using Different Molding and Final Impression Materials on the Retention of Complete Denture Bases
}

\author{
Zeinab Elbadry Mustafa Mohammed ${ }^{{ }^{1}}$, Ehab Mohamed Abd El-Haleim ${ }^{1}$, \\ Mahmoud Mohamed Ammar*1
}

Codex : 17/2020/10

Aadj@azhar.edu.eg

\section{KEYWORDS}

Complete denture,

Low fusing compound,

Putty type condensation silicon,

Metallic zinc- oxide eugenol,

Medium body condensation silicon.

1. Department of Removable Prosthodontics, Faculty of Dental Medicine; (Assuit, boys), Al-Azhar University, Egypt.

* Corresponding Author e-mail: Mahmoudammar@azhar.edu.eg

\section{ABSTRACT}

Aim : It is for comparing the retention of complete denture bases made by border molding using the low fusing compound and putty type condensation silicon by using metallic zinc- oxide eugenol and medium body condensation silicon as final impression material.. Subjects and Methods: the study was carried out on 20 patients , the selected was completely edentulous with well-developed ridge four dentures for each patient was fabricated :( Group A):border molding with green stick compound and final impression with zinc oxide eugenol(Group B): border molding with green stick compound and medium body rubber base as a final impression(Group C): border molding with putty type and medium body condensation silicon as a final impression materials(Group D): border molding with putty type condensation silicon and medium body rubber base as a final impression. Results: Statistically significant results were in complete denture obtained from putty type border molding and medium body condensation silicon final impression, while the least values obtained from green stick border molding and zinc oxide eugenol final impression. Conclusion: Based on the favourable results of this study, it can summarized that the complete denture obtained from putty type and medium body condensation silicone more retentive than other complete dentures obtained from other border molding and final impression materials.

\section{INTRODUCTION}

One of the important parts of dental education and practice is the complete denture prosthodontic ${ }^{(1)}$, since the teeth loss leads to disability and impairment, and teeth restoration lead to improvement in the life quality throughout the oral health improvement ${ }^{(2)}$.

Complete denture prosthesis involves the replacement of the lost natural teeth and associated structures of the maxilla and the mandible. ${ }^{(3)}$

Patients requirements of complete denture are to restore the normal contour, function, esthetics and speech. Most of these goals are accomplished through achieving retention. Retention is directly proportional 
to the adaptation of the base to the supporting oral tissues. Border seal and to a lesser degree to the surface tension at the periphery. ${ }^{(4)}$

One of the important factors in complete denture retention is the border seal which is the biological factor that involves contact of the denture borders with the surrounding oral soft tissues ${ }^{(5)}$.

Border molding considered to be as an important step in the complete denture fabrication since the retention of complete denture depend on several factors as the biological ,physical and mechanical these factors could be achieved by mean of an accurate border molding followed by an accurate final impression $^{(6)}$.

\section{MATERIALS, PATIENTS AND METHODS}

This study was conducted on twenty complete denture patients they were selected from the outpatient clinic of prosthodontic department, faculty of dental medicine ,Al-Azhar university,Assiut branch. Patient ages ranged from 55to 65years old .All of patient with well developed arch ridges .Educated patient with good physical capability to carry out the instruction. Free from any systemic diseases (un controlled diabetes mellitus, severe chronic renal diseases or chronic liver disease and other debilitating diseases )that may affect the prognosis of the prosthesis. Written informed content was obtained from each patient after a full explanation of the study. An accurate maxillary and mandibular primary impressions were made for each patient with alginate impression materials (Tropicalgin. Badiapolesine(Rovigo)Ittaly) fig. (2) and poured with dental stone(Zhermach technical, Italy), producing study casts .

An acrylic custom tray was fabricated (Auto polymerized acrylic resin Acrostone, Egypt), custom tray should be shortening by $2 \mathrm{~mm}$ from vestibular depth all around the prefer of the borders .

Group A: Border molding doing with green stick compound( Kerr U.K . Limited, Netherlands) and final impression with zinc oxide eugenol (Cavex outline, Netherlands).

Group B: Border molding doing with greenstick compound and final impression with medium body rubber base( Zhermack, Zetaplus, Condensation silicon).

Group C: Border molding doing with putty rubber base( Zhermack, Zetaplus ,Condensation silicon) and final impression with zinc oxide eugenol.

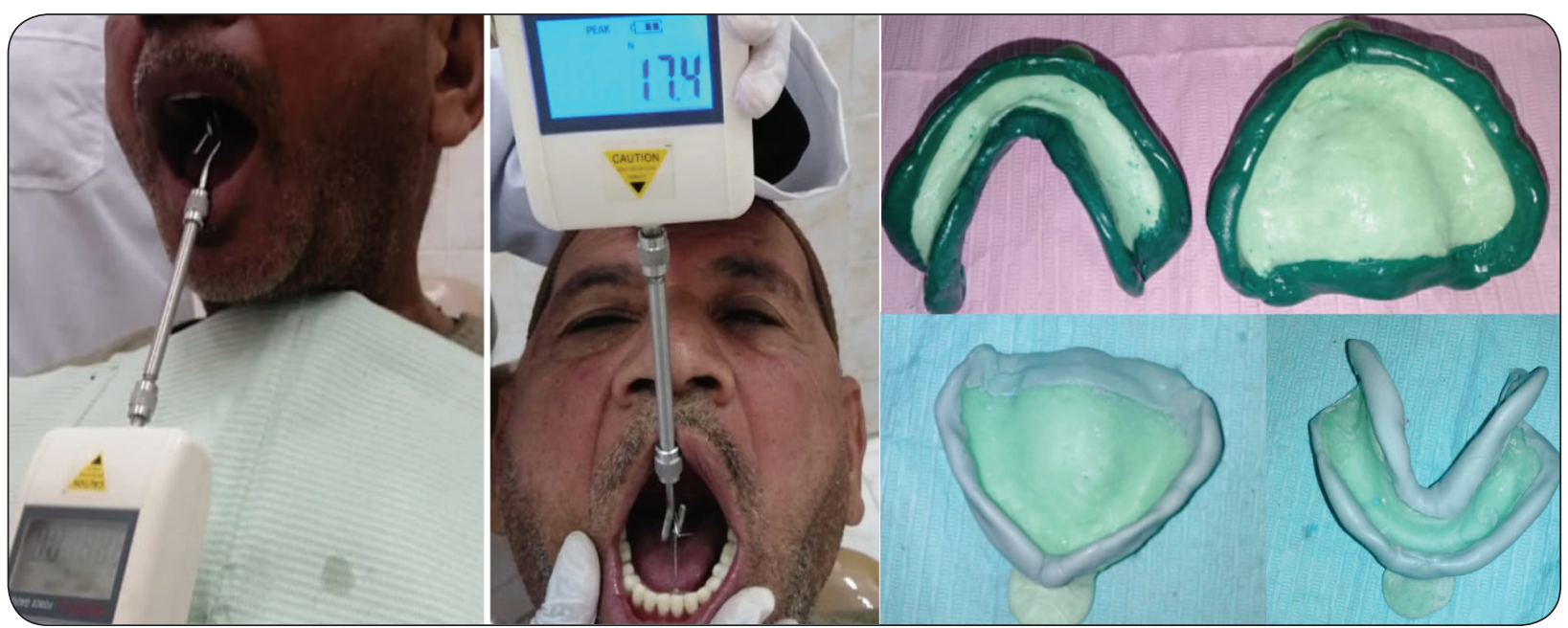

Fig. (1) Pulling the denture during measurement. border molding and final with green stick compound and zinc oxide eugenol matreials 
Group D: Border molding doing with putty rubber base and final impression with medium body rubber base.

The retention of maxillary denture was tested by measuring the force required to dislodge the denture from the basal seat using digital force meter.

\section{RESULTS}

There was a statistically significant difference between $(\mathrm{ZnO})$ and (Medium rubber base) groups where $(p<0.001)$.

The highest mean value was found in (Medium rubber base), while the least mean value was found in $(\mathrm{ZnO})$ group.

There was no statistically significant difference between $(\mathrm{ZnO})$ and (Medium rubber base) groups where $(p=0.103)$.The highest mean value was found in (Medium rubber base), while the least mean value was found in $(\mathrm{ZnO})$ group.

\begin{tabular}{|c|c|c|c|c|c|}
\hline \multirow{3}{*}{ Variables } & \multicolumn{5}{|c|}{ Upper denture } \\
\hline & \multicolumn{2}{|c|}{ Green stick } & \multicolumn{2}{|c|}{$\begin{array}{l}\text { Putty rubber } \\
\text { base }\end{array}$} & \multirow[t]{2}{*}{ p-value } \\
\hline & Mean & SD & Mean & SD & \\
\hline $\mathrm{ZnO}$ & 18.64 & 5.65 & 26.91 & 3.29 & $<0.001^{*}$ \\
\hline $\begin{array}{l}\text { Medium rub- } \\
\text { ber base }\end{array}$ & 25.96 & 3.26 & 32.00 & 9.06 & $0.017^{*}$ \\
\hline p-value & \multicolumn{2}{|c|}{$<0.001^{*}$} & \multicolumn{2}{|c|}{$0.103 \mathrm{~ns}$} & \\
\hline
\end{tabular}

The mean, standard deviation (SD) values of retention of differentgroups of upper denture.

\begin{tabular}{|c|c|c|c|c|c|}
\hline \multirow{3}{*}{ Variables } & \multicolumn{5}{|c|}{ Lower denture base } \\
\hline & \multicolumn{2}{|c|}{ Green stick } & \multicolumn{2}{|c|}{$\begin{array}{c}\text { Putty rubber } \\
\text { base }\end{array}$} & \multirow[t]{2}{*}{ p-value } \\
\hline & Mean & SD & Mean & SD & \\
\hline $\mathrm{ZnO}$ & 11.98 & 2.00 & 18.83 & 3.88 & $<0.001^{*}$ \\
\hline $\begin{array}{c}\text { Medium } \\
\text { rubber base }\end{array}$ & 19.57 & 1.74 & 23.23 & 1.70 & $<0.001^{*}$ \\
\hline p-value & \multicolumn{2}{|c|}{$<0.001^{*}$} & \multicolumn{2}{|c|}{$0.002^{*}$} & \\
\hline
\end{tabular}

The mean, standard deviation (SD) values of retention of different groups of Lower denture base.

\section{DISCUSSION}

Proper recording of the denture bearing area in complete denture is crucial for the preservation of the health of tissues and underlying bone, function, as well as proper retention of the dentures .The recording of tissues in oral cavity is difficult due to factors, such as salivation, blood flow and sulcular fluid $^{(7)}$

Border molding impression by modeling plastic has been used since 1907. Around 1950, border molding with tracing compound was accepted as standardized technique by most prosthodontists .Various surveys showed modeling plastic impression compound and zinc oxide eugenol impression paste is most popular material used for complete denture impression. But there is distinct trend for increasing use of polyvinyl siloxane for border molding procedures and impression of edentulous arches. ${ }^{(8)}$

Polyvinyl siloxane also known as addition siloxane is dimensionally stable and record fine detail and can be poured at the comfort of the operator. PVS has excellent physical properties and handling characteristic and has the best elastic recovery of all available impression materials. This material can be poured 1 week after impression taken and can do multiple pour. Disadvantage of PVS are that the material is more rigid and to much costly practitioner use irreversible hydrocolloid mostly. ${ }^{(9)}$.

The statistical analysis of the data obtained indicated that the higher mean of retention forces were found in the denture bases were fabricated by using the full putty silicone border molding a combined with medium body silicone final impression these results could be explained on the bases, that the putty silicone tracing characterized by an excellent manipulative consistencies dimensional stability and being molding by fingers prior to be inserted intra orally with an adequate working times, All these facts explain the higher retention forces and its statistically highly significant difference as compared 
to retention forces of denture bases produced by full green stick tracing and metallic oxide final impression, this may be clarified by the facts that during softening procedure, green stick by dry heat flame, this may have resulting in flow and texture properties of green stick material, since the flow will be retained for a short period of time, as its in contact with hot water \& oral tissues, the green stick cool and flow ceased this may be resulted in an inaccurate impression and if tissues are contacted before tray is properly seated for border molding procedure. These finding are in line with the findings of Rizk2008 and Yarapatineni et al. 2013, Anna Jone 2017 and Mohammad Arif Lon 2019.

\section{CONCLUSION}

Complete dentures obtained from putty type border molding and medium body condensation silicon final impression materials is higher in retention in maxillary and lower complete dentures.

The denture bases produced by full green final impression material showed the lowest mean values of retention forces

All the retention forces of all denture bases showed an acceptable retention forces on clinical examination.

\section{REFERENCES}

1. Jayaprakash MB., Sahu K, Khan M, et al.( Management of flabby ridge cases: A chanllenge in clinical practice.) Int. adv health sci 2014; 1(5): 32-7.

2. Tasleem R, Bin Saeed MH, Javed MU. (Comparison of complete denture fabricated by two different border molding materials, interms of patients' satisfaction.) $\mathrm{J}$ Ayub Med Coll Abbottabad 2013; 26(3-4): 78-8 .

3. Academy of prosthodontic terms J. prosth.demt. 2005.94(1).15-81.

4. Renu B Pachar, Youginder Singla, Prince Kumar. (Evaluation and Comparison of the Effect of Different Border Molding Materials on Complete Denture Retention) The Journal of Contemporary Dental Practice, August 2018;19(8):982-987.

5. Patel JR, Sethuraman R, Chaudhari J.( Comparative evaluation of border morphology produced by three different border molding materials.) Int. Journal of Contemporary Dentistry 2010; 1(3).

6. Olivieri A, Zuccari AG, Olivieri D. (A technique for border molding with light - polymerized resin. )J Prosthet Dent 2003; 90: 101 .

7. Punj A., Bompolaki D., \&Garaicoa J. (2017). Dental impression material and techniques. Dent clin N Am 2017 (61), $779-796$

8. Jankar, A., Nilawar, S., Magar, S., \&Mutneja, P. Impression Material and techniques used and followed for the fixed partial denture treatment by private dental practitioners in Maharashtra state: a questionnaire study. International journal of healthcare and biomedical research, (2016). 4, 83-92. 


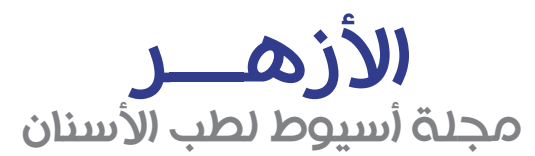

النشر الرسمي لكلية طب الأسنان

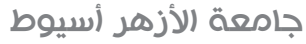

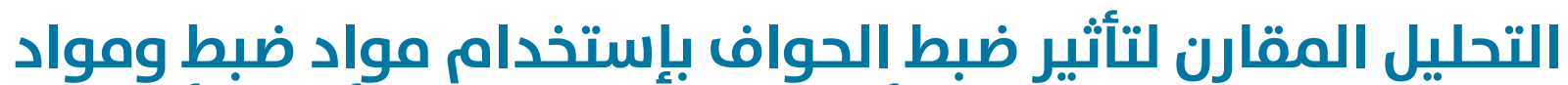

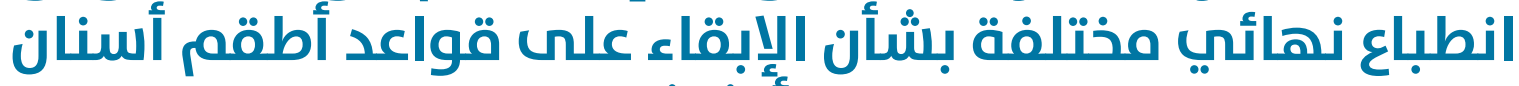 كاملة أكثر ثباتا
}

\author{
زينب البدرى مصطفى محمد، إيهاب محمد عبدالحليه، محمود محمد عمار \\ 1. قسـم الاستعاضة الصناعية المتحركة ، كلية طب الاسنان ، (بنين - اسيوط)، جامعة الأزهر، مصر الإنسر \\ MAHMOUDAMMAR@AZHAR.EDU.EG *
}

الملخص :

الهـدف : رليل مقارن لتأثير ضبط الحواف بإستخدام مواد ضبط ومواد إنطباع نهائي مختلفة بشأن الإبقاء على قواعد أطقم أسنان كاملة أكثر ثباتا.

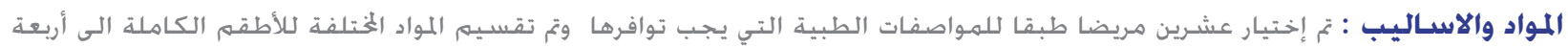

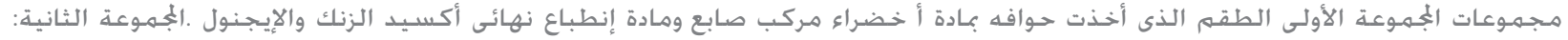

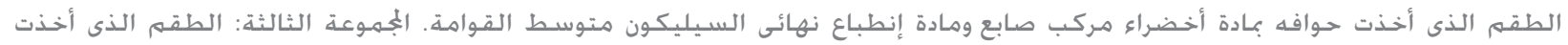

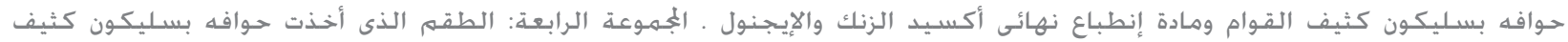

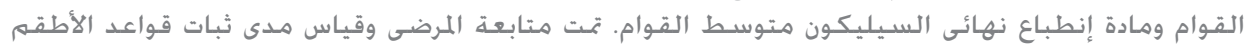

النتائج : تم تحليل النتائج إحصائيا وقد أظهرت النتائج التالية: أن هناك فرق إحصائي طفيف بين الجمهوعات في مدى ثبات قواعد الأطقم حيث

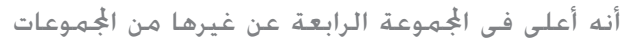
الخلاصة: أنه يفضل عمل الأطقم الكاملة من مواد أخذ حواف ومواد إنطباع نهائي من السيلكون كثيف ومتوسط القوام. . الكلمات المفتاحية: أطقهم أسنان كاملة، ومادة انطباع نهائي أكسيد الزنك، ومادة انطباع نهائي السيليكون متوسط القوامة، ومواد انطباع نهائي، ضبط المفواف ألماف 